Revista Brasil. Bot., V.30, n.4, p.687-694, out.-dez. 2007

\title{
Vegetative propagation strategies of four rupestrian species of Leiothrix (Eriocaulaceae)
}

\author{
FLÁVIA DE FREITAS COELHO ${ }^{1,2}$, CHRISTINA DORVALINA LOPES CAPELO', \\ ANA CAROLINA OLIVEIRA NEVES ${ }^{1}$ and JOSÉ EUGÊNIO CÔRTES FIGUEIRA ${ }^{1}$
}

(received: September 15, 2004; accepted: January 16, 2007)

\begin{abstract}
Vegetative propagation strategies of four rupestrian species of Leiothrix (Eriocaulaceae)). Leiothrix is endemic of South America and includes 37 species, 25 of which occur in the state of Minas Gerais. Nineteen of those occur in the "Serra do Cipó", a mountain chain, located in the southern portion of the Espinhaço mountain range. This study examines vegetative propagation strategies of four species of Leiothrix, endemic to the Minas Gerais portion of the Espinhaço mountain range. For each species we established permanent plots, where we marked 30 to 51 rosettes or clones, and then took morphological and phenological measurements. Leiothrix crassifolia (Bong.) Ruhland and L. curvifolia var. lanuginosa (Bong.) Ruhland are rhizomatous, forming compact clones. Leiothrix vivipara (Bong.) Ruhland does not produce rhizomes, but is pseudoviviparous, i.e., produces numerous ramets originating from inflorescences. These ramets are formed precociously, and the flower heads do not touch the ground. In Leiothrix spiralis (Bong.) Ruhland both of these strategies are seen: it is both rhizomatous and pseudoviviparous. In this species, the ramets are formed late, only after the flower head has touched the ground. One of the typical conditions of the rupestrian grasslands is soil water shortage in some periods of the year and nutrient scarcity all year round. These conditions might have created an ideal ecological scenario for the evolution of both pseudovivipary and rhizomatous clonal growth in Leiothrix.
\end{abstract}

Key words - clonal growth, Eriocaulaceae, Leiothrix, pseudovivipary, rupestrian grasslands

RESUMO - (Estratégias de propagação vegetativa de quatro espécies rupestres de Leiothrix (Eriocaulaceae)). Leiothrix é endêmico da América do Sul e inclui 37 espécies, 25 das quais ocorrem em Minas Gerais, 19 delas na Serra do Cipó. Descrevemos as estratégias de propagação vegetativa em quatro espécies de Leiothrix, endêmicas à porção mineira da Cadeia do Espinhaço. Para cada espécie estabelecemos parcelas permanentes, marcamos de 30 a 51 rosetas ou clones e tomamos medidas morfológicas e fenológicas. Leiothrix crassifolia (Bong.) Ruhland e L. curvifolia var. lanuginosa (Bong.) Ruhland são rizomatosas e formam clones compactos do tipo falange. Leiothrix vivipara (Bong.) Ruhland não produz rizomas, mas é pseudovivípara, produzindo numerosos rametes originários da inflorescência. Esses rametes são formados precocemente, sem os capítulos tocarem o solo. Leiothrix spiralis (Bong.) Ruhland possui as duas formas de crescimento clonal: é rizomatosa e pseudovivípara. Nesta espécie, os rametes são formados tardiamente, somente depois do capítulo tocar o solo. Uma das condições típicas dos campos rupestres é a escassez de água no solo em alguns períodos do ano, além da escassez de nutrientes durante todo o ano. Estas condições podem ter criado um cenário ecológico ideal para a evolução de pseudoviviparidade e do crescimento rizomatoso em Leiothrix.

Palavras-chave - campos rupestres, crescimento clonal, Eriocaulaceae, Leiothrix, pseudoviviparidade

\section{Introduction}

Many clonal species can produce offspring both through clonal propagation (asexual reproduction) and sexual reproduction (Worley \& Harder 1996). The functional differences between sexual and clonal reproduction and the influence of selective factors affect reproductive strategies of clonal species (Harper 1977). Each of these reproductive modes differs in dispersal distance and in the phenology of offspring production and establishment (Winkler \& Fischer 2002).

1. Universidade Federal de Minas Gerais, Instituto de Ciências Biológicas, Departamento de Biologia Geral, Laboratório de Ecologia de Populações, Caixa Postal 486, 30161-970 Belo Horizonte, MG, Brazil.

2. Corresponding author: flaviafcoelho@yahoo.com.br
The fragmentation and formation of stolons or rhizomes are the main types of clonal growth. Another rare type of clonal growth, described for only 50 species of angiosperms, is pseudovivipary (Elmqvist \& Cox 1996). In this case, the inflorescences, instead of the flowers, produce ramets asexually (Elmqvist \& Cox 1996). Several authors have argued that pseudovivipary has evolved in response to a short growing season (e.g. Lee \& Harmer 1980, Elmqvist \& Cox 1996). In areas of mediterranean and semi-arid climates, pseudovivipary has also been correlated with the ability of plants to grow in dry soil (Salisbury 1942).

Although known to occur in many plant families (e.g. Alliaceae, Liliaceae, Agavaceae, Poaceae, Saxifragaceae, and Polygonaceae), pseudovivipary had not been previously found in the Eriocaulaceae (for review see Elmqvist \& 
Cox 1996). Most species in this family occur in the rupestrian grasslands of the Espinhaço mountain chain, above 1,000-1,100 m, on shallow and sandy soils, and rocks mostly of quartzites and sandstones (Giulietti 1990). Many Eriocaulaceae species possess the capacity for inflorescence proliferation (Giulietti 1978), however pseudovivipary is not always found.

The genus Leiothrix is restricted to South America and contains 37 species (Giulietti \& Hensold 1990). Except for L.flavescens (Bong.) Ruhland that occurs in Brazil, Venezuela, Guyana, and Peru, and L. celiae Moldenke that is exclusive to Venezuela, the remaining species are endemic of small mountainous areas in the Brazilian states of Minas Gerais and Bahia (Giulietti et al. 1994). The majority of the species in this genus have limited distribution, because they do not possess mechanisms especially adapted to long-distance dispersal (Giulietti et al. 1994). The highest species richness of Leiothrix is concentrated in the mountains of Minas Gerais, where 25 species occur, 19 in the "Serra do Cipó" (Giulietti \& Hensold 1990).

Sympatric species of Leiothrix in "Serra do Cipó", our study site, have sexual reproduction, and/or clonal reproduction via rhizomes, and/or clonal reproduction via pseudovivipary (Coelho et al. 2005). The flower heads of Leiothrix subg. Stephanophyllum are called "proliferous flower heads", because they originate vegetative shoots out of reproductive organs by means of sprouting of meristematic cells (Giulietti et al. 1994). This flexibility in reproductive mode could enhance the persistence of the population at the local habitats, where they are subjected to water and nutrient scarcity. However, many such species have an elevated risk of extinction, given their small range of occurrence and also local occurrence of fires and illegal extraction (Giulietti et al. 1987). Therefore, data concerning the biology of these species might be necessary to aid in management and or conservation plans. Moreover, comparing life history traits of closely related sympatric species may yield valuable information regarding the evolutionary history of the group.

This study describes the vegetative propagation strategies of Leiothrix curvifolia var. lanuginosa (Bong.) Ruhland, L. crassifolia (Bong.) Ruhland, L. spiralis (Bong.) Ruhland and L. vivipara (Bong.) Ruhland. Populations of these species are easily found in our study site, except for L. curvifolia var. lanuginosa. This variety, apart from being abundant in other locations, where it occurs, has low regional frequency (Giulietti 1978). Furthermore, we provide a first description of natural history and flowering phenology of these species.

\section{Materials and methods}

Study area - "Serra do Cipó" is located south of the Espinhaço mountain range, between $19^{\circ} 12^{\prime}-19^{\circ} 20^{\prime} \mathrm{S}$ and $40^{\circ} 30^{\prime}$ $43^{\circ} 40^{\prime} \mathrm{W}$, altitude often higher than $1,000-1,100 \mathrm{~m}$. The climate is mesothermic with mild summers and a rainy period during the summer. Temperatures vary from 17 to $20{ }^{\circ} \mathrm{C}$. The annual precipitation is nearly $1,500 \mathrm{~mm}$, with a dry period of six to seven months during the winter, and a moist period that lasts five to six months. The soils throughout the Espinhaço mountain range and the "Serra do Cipó" are usually shallow and sandy, with rocky outcrops mostly of quartzite and sandstones (Giulietti et al. 1987).

The vegetation of "Serra do Cipó" is diverse, comprising mainly rupestrian grasslands. It has a continuous herbaceous layer with sparse shrubs. The rosette shape is a morphological convergence occurring for various families of herb plants (Menezes \& Giulietti 1986). Poaceae, Cyperaceae, Velloziaceae, Xyridaceae and Eriocaulaceae are quite common in the region (Giulietti et al. 1987).

The study populations of Leiothrix curvifolia var. lanuginosa, L. spiralis, L. vivipara, and L. crassifolia were located inside of the "Parque Nacional da Serra do Cipó". Data collection and analysis - For each species we established permanent plots $(3 \times 1.5 \mathrm{~m})$, where we labeled with aluminum tags from 30 to 51 rosettes and/or clones. We took the following measurements: 1) rosette diameter; 2) number of flower heads per rosette; 3 ) number of flower heads that originated rosettes; 4) maximum length of scapes; 5) dispersal distance of ramets; 6) frequency of ramet formation connected by rhizomes; and 7) frequency of ramet formation from flower heads. The measurements for all four species were taken between February and August of 2003. We used 100 rosettes of each species for the measurements of frequency of ramet formation from rhizomes or flower heads.

The frequency with which rosettes originated from flower heads or rhizome allowed us to evaluate the relative importance of these two types of clonal expansion. We classified the rosettes according to their origin (figure 1). We tested the clonal dispersal potential as the relationship between the maximum length of the scapes and the dispersal distance of ramets using Pearson correlation (Sokal \& Rohlf 1981). We also used a reference line $\mathrm{y}=\mathrm{x}$. Points along the line $\mathrm{y}=\mathrm{x}$ indicate the maximum use of the dispersal potential of the ramets via scape.

Finally, we collected soil samples at three random points in the vicinities of L. curvifolia var. lanuginosa plots in monthly intervals from December 2003 to December 2004. In each month, we recorded presence or absence of trichomes on rosettes of L. curvifolia var. lanuginosa. This is the only species among the four studied that produces trichomes. The soil samples were obtained with the help of a custom-built penetrometer $(2.0 \mathrm{~cm}$ diameter and $5.0 \mathrm{~cm}$ depth). In the laboratory, samples were dried at $60{ }^{\circ} \mathrm{C}$ for at least $48 \mathrm{~h}$ for dry weight determination. We determined the amount of water in the soil through the following calculation: $g_{\text {water }}$ in 


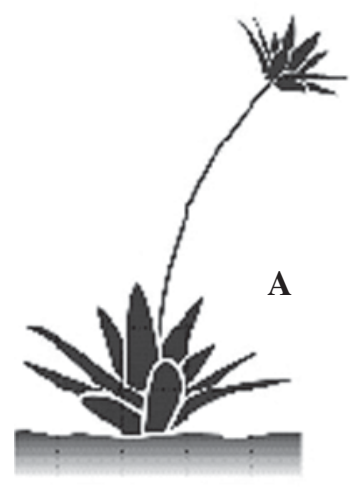

C

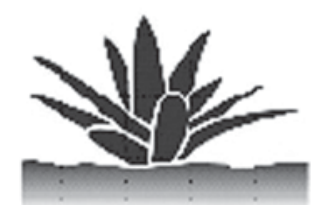

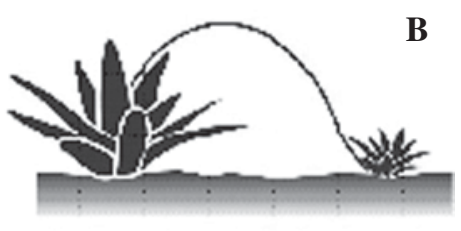

D

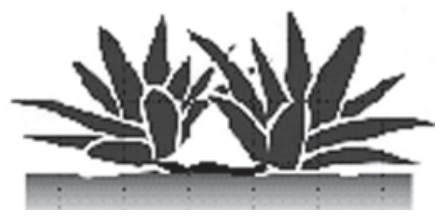

Figure 1. Schematic illustration of the types of rosette development. A. originated from flower heads, without touching the soil; B. originated from flower heads that attach to the soil; C. isolated; D. connected by rhizomes.

the soil $=$ soil fresh weight - soil dry weight. We utilized Spearman's rank correlations for soil moisture in relation to presence or absence of trichomes on rosettes from December 2003 to December 2004.

\section{Results}

Vegetative propagation and natural history - The species studied can be characterized according to their types of sexual and clonal reproduction (table 1). At one extreme, we find species that sexually reproduce and give rise to numerous ramets originated from rhizomes, forming compact clones (e.g., Leiothrix curvifolia var. lanuginosa and $L$. crassifolia; figures 2, 3). On the other extreme, there are those that reproduce sexually or not, produce few or no ramets originating from rhizomes, but produce numerous ramets originating from inflorescences, forming more dispersed clones (e.g., L. vivipara; figure $4)$. Between these extremes there appears to have been a gradual loss in the capacity for clonal proliferation by means of rhizomes, and an increase in the capacity to
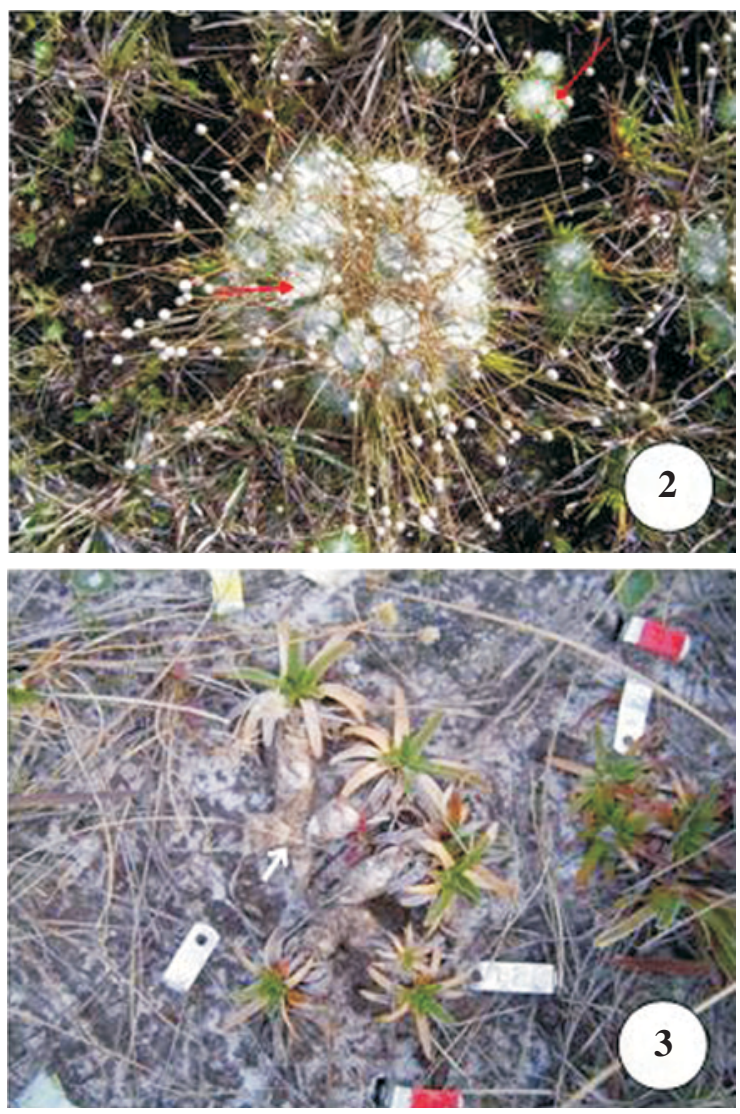

Figure 2. Rosettes of Leiothrix curvifolia var. lanuginosa forming a compact clone originating from rhizomes. Note the presence of white tricomes surrounding the leaves (red arrows). Figure 3. Rosettes of L. crassifolia with exposed rhizomes (white arrow) forming a compact clone.

Table 1. Comparison of vegetative propagation strategies of Leiothrix curvifolia, L. crassifolia, L. spiralis, and L. vivipara. $(\mathrm{RFH}=$ ramet originated from flower head.)

\begin{tabular}{llccc}
\hline Species & Clonal growth & $\begin{array}{c}\text { Production } \\
\text { of RFH }\end{array}$ & $\begin{array}{c}\text { Position } \\
\text { of RFH }\end{array}$ & $\begin{array}{c}\text { Production of seeds } \\
\text { (reference) }\end{array}$ \\
\hline L. curvifolia & rhizomatous (phalanx) & none & none & many (Giulietti 1978) \\
L. crassifolia & rhizomatous (phalanx) & none & none & many (Giulietti 1978) \\
L. spiralis & rhizomatous (phalanx)/ & late & rooted & few (Giulietti 1978) \\
L. vivipara & pseudoviviparous (guerrilla) & precocious & $\begin{array}{c}\text { mostly suspended, } \\
\text { supported by the scape }\end{array}$ & rare (Giulietti 1978) \\
\hline
\end{tabular}


form ramets by pseudovivipary (originating from flower heads): L. spiralis is capable of forming the two types of rosette, yet pseudovivipary predominates (figure 5).

Leiothrix curvifolia and L. crassifolia occur in sandy soils with a low density of herbs. Their scapes are rigid, relatively short, and exit the rosette at high angles in relation to ground level. Flower head production is intense in these species: on average 15 flower heads are produced per ramet in clones of $L$. curvifolia, and nine flower heads per ramet in clones of $L$. crassifolia. The flower heads generally touch the ground when the scapes become curved, at the end of the reproductive season. Seeds fall in proximity to the mother rosettes. Leiothrix crassifolia and $L$. curvifolia are ring-forming clonal species (sensu Wikberg \& Svensson 2003). The rosettes at the center of the clone die as they get old, leaving the rhizomes exposed (figure 3).
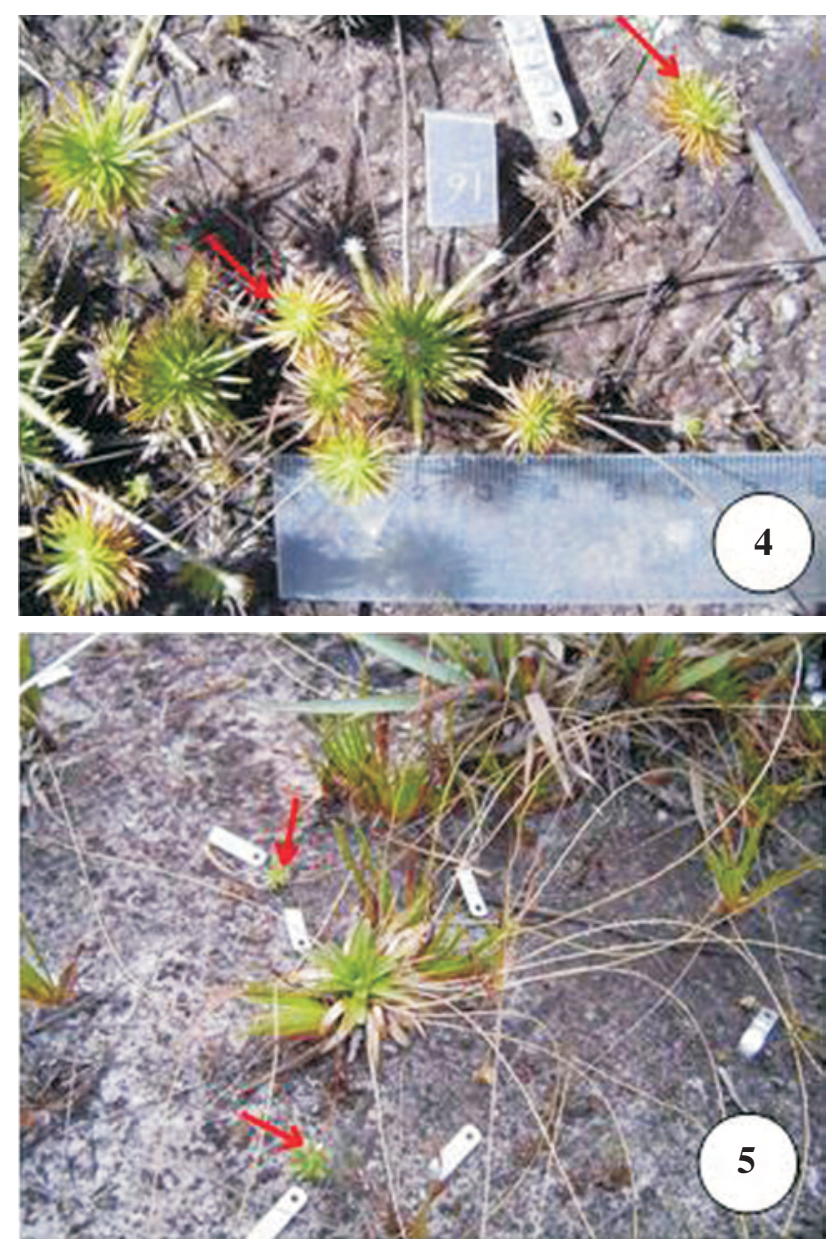

Figure 4. Rosettes of Leiothrix vivipara with scapes. Some ramets are rooted and attached to the parent plant by scapes (red arrows), but the majority remain suspended without touching the ground (white arrows). Figure 5. Rosettes of L. spiralis with scapes. Note the ramets attached to the parent plant by scapes.
During the dry season, L. curvifolia var. lanuginosa produces numerous white trichomes, which completely surround the leaves. Even the young rosettes, approximately $0.5 \mathrm{~cm}$ in diameter, present trichomes (figure 3). The presence of trichomes on leaves is so intense that it gives the plant a cotton-like appearance when observed at close range. In the period of greater soil water availability, trichomes are not observed on the rosettes (figure 6).

Leiothrix vivipara occurs in dry, sandy soils that may or may not be densely covered by a herbaceous layer. The majority of the ramets remains suspended by scapes or intertwined with herbaceous leaves (Coelho et al. 2005). Suspended ramets are much more numerous than ramets attached to the ground (figure 4). The formation of ramets originating from flower heads is precocious. It occurs soon after the formation of the flower heads, and without entering in contact with the ground. The flower heads of the ramets also proliferate giving rise to leaves and scapes. This process may repeat itself several times. In this species, there is a reduction in the number of flowers per flower head, since the central portion of the flower heads is almost entirely taken up by leaves (Giulietti 1978).

Leiothrix spiralis occurs, preferentially, in sparse vegetation area. The scapes are flexible and arched when the ramets begin to form in the center of the flower heads. In this phase, the scape bends and flower heads with floral buttons touch the ground, initiating the formation of binding roots. Rosettes of $L$. spiralis are morphologically very similar to the rosettes of $L$. crassifolia. In all, contrary to $L$. crassifolia, in $L$. spiralis the establishment of ramets by way of rhizomes is rare. In addition, the scapes of $L$. spiralis are flexible and arched while those of $L$. crassifolia are short and rigid.

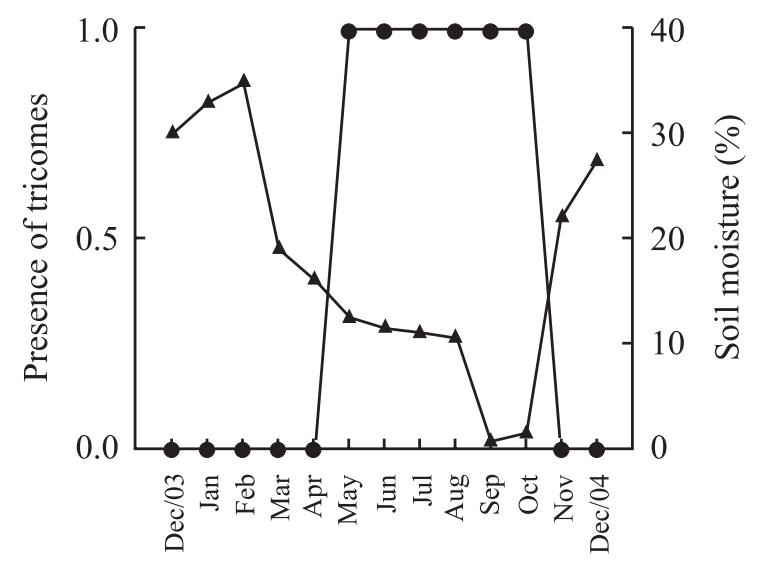

Figure 6. Presence of trichomes ( $\bullet$ ) on leaves of Leiothrix curvifolia var. lanuginosa as a function of the monthly variation in percentage soil moisture $(\mathbf{\Lambda})$. 
Rosette morphology - Rosettes of L. crassifolia and $L$. curvifolia var. lanuginosa are similar as for the average diameter and minimum diameter for flowering (table 2). Both species form compact clones with short connections and of long duration. Lovett Doust (1981) used the term phalanx strategy to describe this form of growth clonal, and the term "guerrilla" to describe clones with long connections and of short duration. Both species showed similar distances between rosette centers (table 2). In L. crassifolia, the number of ramets varied from 1 to $44(n=100)$ (figure 7A), while in $L$. curvifolia var. lanuginosa the number of ramets per clone varied from 1 to $21(n=100)$ (figure 7B).

The frequency of isolated rosettes in L. spiralis is larger than in the other species (figure 7C). The number of ramets per clone in this species varied only from 1 to $5(n=100)$. The scapes are larger than in the other species, which are not pseudoviviparous (table 2). As the L. spiralis flower heads mature, the scapes grow and become arched to the point that the flower heads touch the ground. Yet, ramets do not fully realize their maximum dispersal potential or, rather, the effective dispersal distance of the ramets is frequently smaller than the maximum distance the scape can reach (figure 8A). Nevertheless, the correlation between scape length and ramet dispersal distance is strong and positive $(r=0.87)$. Contrary to L. spiralis, in $L$. vivipara the maximum length attained by the scape is frequently equal to the ramet dispersal distance $(r=0.97)$ (figure 8B). Maximum length of the scape with rooted rosettes in L. spiralis and L. vivipara (table 2) indicates clones with a "guerrilla" growth form, which possess a widely spaced set of ramets.

Among the species studied, L. vivipara is the only one to form ramets supported for a lifetime by the scapes (table 2). In this clonal growth form, most of the ramets do not touch the ground. They remain suspended and form a type of "canopy". This clonal growth form differs completely from that in which the ramets remain rooted that are widely spaced in the ground and can become independent of the rosette-mother when the stem breaks.
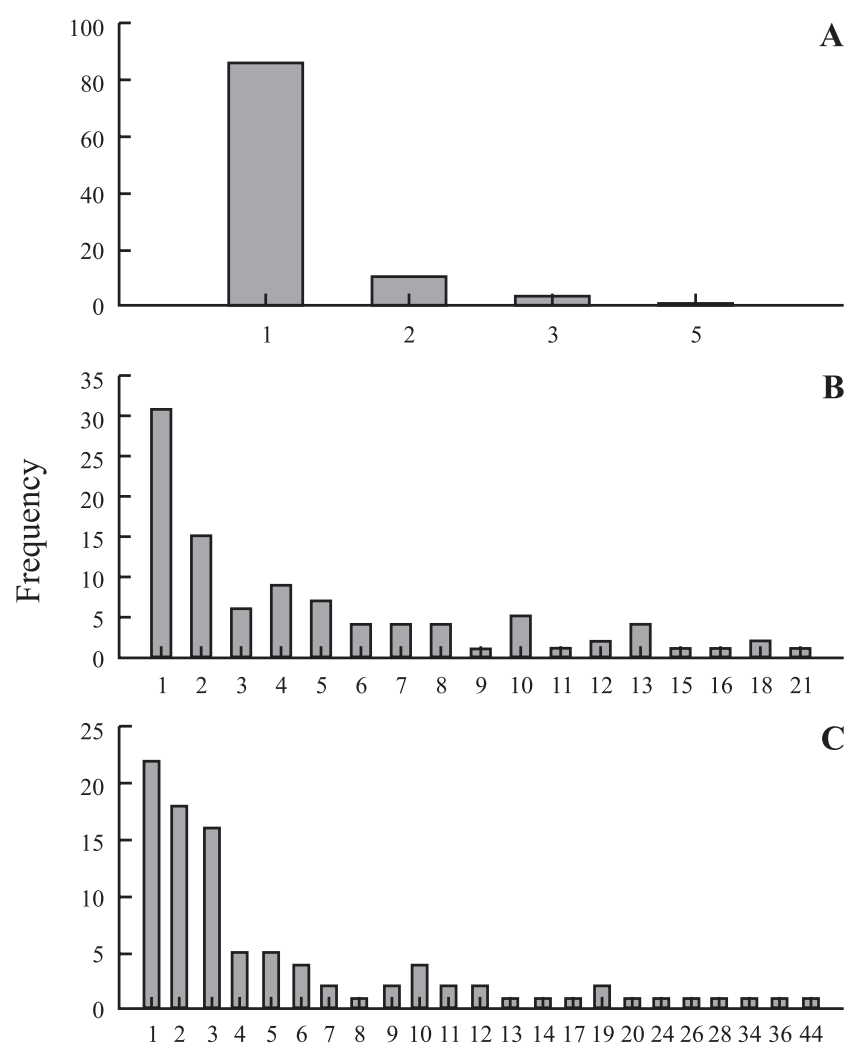

Ramets per genets

Figure 7. Frequency distribution of rosettes originated from rhizomes by clone (ramet number by genet) in 100 genets. A. Leiothrix spiralis. B. L. curvifolia var. lanuginosa. C. $L$. crassifolia.

Reproductive phenology - Table 3 shows the number of produced flower heads and ramets for all studied species. Of the $30 \mathrm{~L}$. crassifolia clones, $74 \%$ produced flower heads, and $26 \%$ reproduced by way of rhizomes, during the rainy season. At the end of the rainy season, $71.6 \%$ of the clones still carried flower heads, although their production had ceased. During the dry season individuals continued to produce no flower heads and many of them were found on the ground, detached from the scapes, near the parent plant.

Table 2. Mean \pm standard error $(\mathrm{cm})$ for morphological measurements of the rosettes for the four study Leiothrix species. $(\mathrm{AD}=$ Average diameter, $\mathrm{RMD}=$ Reproductive minimum diameter, $\mathrm{ALS}=$ Average length of the scape, MLS-RR $=$ Maximum length of the scape with rooted rosettes, MLS-SR = Maximum length of the scape with suspended rosettes, and ADRC-PHC $=$ average distances between reproductive rosette centers in the phalanx clones).

\begin{tabular}{lcccccc}
\hline Species & AD & RMD & ALS & MLS-RR & MLS-SR & ADRC-PHC \\
\hline L. curvifolia & $4.0( \pm 0.3)$ & $2.0( \pm 0.4)$ & $6.0( \pm 0.6)$ & - & - & $3.1( \pm 1.9)$ \\
L. crassifolia & $4.3( \pm 0.2)$ & $2.2( \pm 0.6)$ & $6.2( \pm 0.2)$ & - & - & $2.5( \pm 1.4)$ \\
L. spiralis & $3.7( \pm 0.3)$ & $1.5( \pm 0.2)$ & $20( \pm 2.8)$ & 40 & - & - \\
L. vivipara & $2.5( \pm 0.1)$ & $0.5( \pm 0.1)$ & $13( \pm 1.3)$ & 32 & 14 & - \\
\hline
\end{tabular}




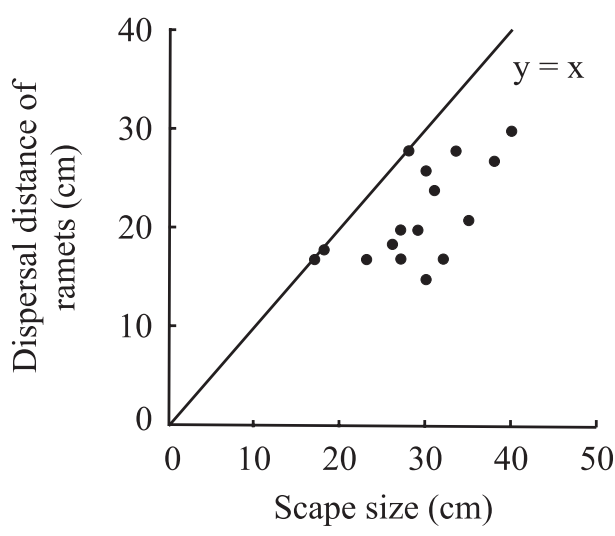

A

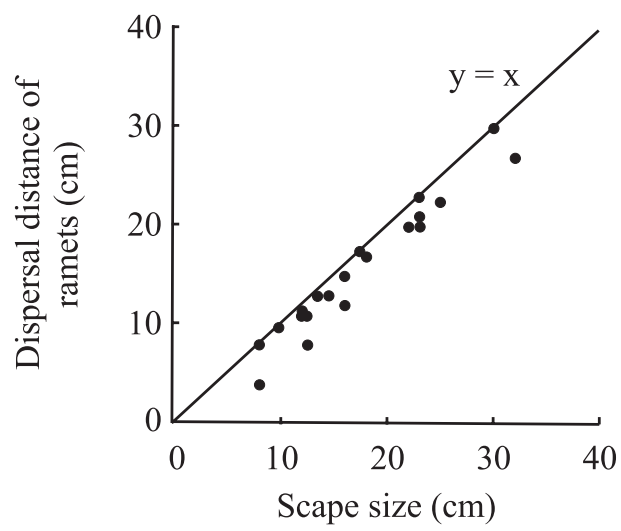

Figure 8. Attachment distance of ramets in regards to scapes length. A. Leiothrix spiralis. B. L. vivipara. Points along line $\mathrm{y}=\mathrm{x}$ indicate the maximum use of the dispersal potential of the ramets via scape.

The percentage of clones that produced flower heads in L. curvifolia var. lanuginosa (84\%) was greater than the percentage of rosettes that produced rhizomes $(16 \%)$. The production of flower heads occurred during the rainy season. During the dry season the flower heads were senescent. At the end of this period, the majority of the flower heads were on the ground near the parent plant.

At the start of the rainy season, L. spiralis showed $68 \%$ of rosettes with flower heads and $32 \%$ of rosettes with ramets originating from pseudovivipary connected by way of scapes. At the end of the rainy season, only $36 \%$ of the rosettes carried flower heads and $48 \%$ already showed ramets originating from flower heads. The remaining rosettes, $16 \%$, had their flower heads broken before the formation of new rosettes

At the start of the rainy season, individuals of Leiothrix vivipara showed only nine flower heads and a total of 52 ramets originated from pseudovivipary, 12 of which were attached to the ground. At the end of the rainy season, there was an abundant production of flower heads: 401 . Both the number of ramets per scape (62) and the number of ramets attached to the ground (24) increased from one season to the next. Of the 401 flower heads, 329 gave rise to ramets.

\section{Discussion}

In most habitats resources are distributed patchily, and often even on small spatial scales (centimeters) (Caldwell \& Pearcy 1994). Therefore, the optimum life histories are not just determined by demographic rates of survival and reproduction, but also depend on dispersal because of spatially heterogeneous conditions for establishment (Winkler \& Fischer 2002).

Our results showed species with rhizomatous growth, forming compact clones (L. crassifolia and L. curvifolia var. lanuginosa), and species with long connections (scapes) (L. vivipara and L. spiralis) which are similar to stolons. The scapes in pseudoviviparous species function like stolons when the flower heads of rosettes proliferate giving rise to plantlets (Coelho et al. 2005). Each one of these modes of clonal growth seems to play different roles in the life cycle of the plant. Thus, rhizomes are structures capable of resources storage (carbohydrates, mineral nutrients, and even water), and may serve as means of avoiding drought and burning (Grace 1993). Therefore, this mode of clonal growth is important on maintenance of $L$. spiralis and L. vivipara populations (Coelho et al. 2006), as

Table 3. Production of flower heads from February to May 2003, ramets originated from flower heads from June to August 2003, and ramets per clone formed by rhizomes in Leiothrix curvifolia, L. crassifolia, L. spiralis and L. vivipara.

\begin{tabular}{lccc}
\hline Species $\left(\mathrm{n}^{*}\right)$ & $\begin{array}{c}\text { Flower heads } \\
\text { number }\end{array}$ & $\begin{array}{c}\text { Ramets originated } \\
\text { from flower heads }\end{array}$ & $\begin{array}{c}\text { Ramets formed by } \\
\text { rhizomes }\end{array}$ \\
\hline L. curvifolia $(51)$ & 989 & None & 191 \\
L. crassifolia (30) & 331 & None & 115 \\
L. spiralis (30) & 79 & 42 & 9 \\
L. vivipara (30) & 401 & 329 & None \\
\hline
\end{tabular}

* number of clones 
well as of L. crassifolia and L. curvifolia var. lanuginosa (Coelho 2005), which are exposed to stressful conditions (drought, fire, lack of nutrients). While, pseudoviviparous reproduction, observed in L. vivipara and L. spiralis, intermediates allocations for growth, when the ramets remain attached to a parental rosette, and reproduction when these connections are split and the ramets become independent. Moreover, the pseudovivipary has been considered one of the most efficient modes for numerical increase of ramets (Grace 1993). This reproductive mode showed a diversification between $L$. spiralis and $L$. vivipara .

In $L$. spiralis, the ramets are formed only after the flower head touches the ground, and during the dry season, the scapes become very fragile and can easily split up (Coelho et al. 2006). Through the splitting connections, each ramet becomes independent of the parental-rosette. Thus, in this species, the pseudovivipary has function of reproduction. This diversification on the pseudoviviparous strategy might have resulted from specific characteristics of their microhabitats, especially from the herbaceous vegetation cover. Some outcrops in the rupestrian grasslands at the "Serra do Cipó" are just constituted of exposed sand, without any vegetation cover. However, on contiguous outcrops a dense vegetation cover can be found, dominated by herbaceous. As in L. spiralis, the ramets are formed only after the flower head touches the ground; few pseudoviviparous ramets of this species grow amongst herbaceous vegetation, which would be an impediment for those plantlets contact with the soil (Coelho et al. 2005).

In contrast to $L$. spiralis, L. vivipara ramets did not split. The formation of their pseudoviviparous ramets is early, it occurs just after flower head formation, and most of them are kept suspended by the scapes. In densely crowded conditions, the scapes remain intertwined with herbaceous leaves (Coelho et al. 2005), and the numerous plantlets produced gain support to reach the top of the herbaceous cover. Because of this growth form, in which vegetative propagules remain attached to parental rosette suspended by the scapes, $L$. vivipara was described as a pseudoviviparous canopy-forming species (Coelho et al. 2006). Ramets of pseudoviviparous plants are photosynthetically active (Lee \& Harmer 1980, Pierce et al. 2003), therefore each suspended plantlet is a photosynthetic unit of a dispersed "canopy" where the light incidence is more intense. To keep suspended by the scapes reaching the top of the herbaceous cover, the plantlets can acquire necessary photosynthates and translocate to the rosettes attached to the soil through their scapes. Similar strategies are also verified in L. flagellaris, where prevails the "canopy" formation (Figueira \& Del Sarto 2007).
Phalanx species (L. crassifolia and L. curvifolia var. lanuginosa) allocate resource entirely for growth, because their connections are more durable and more resistant to split up. Besides the formation of compact clones, L. curvifolia var. lanuginosa developed, in the dry period, trichomes on leaves thereby maintaining the rosettes humid, impeding their desiccation. In alpine, arid, or other areas which resemble rupestrian grasslands, patches that permit growth and survival of a particular species may be sparsely distributed, both in time and space. Under these circumstances, there may be little chance that a propagule (sexual or asexual), through dispersion, will find better growing conditions in a different patch than its parents (Elmqvist \& Cox 1996). Moreover, phalanx species appear to possess a greater ability to exploit small nutrient-poor patches (Humphrey \& Pyke 1998, van Groenendael et al. 1996). In addition, rhizomes are usually thought to store buds and resources in order to be able to regenerate in more favorable conditions (Grace 1993). Therefore, the rupestrian grasslands with their marked seasonality and nutrient-poor and dry conditions, might have acted as strong selective pressure toward of this clonal growth form.

The results presented are based on the strategies of reproduction and clonal growth of four of the 19 species which occur in the "Serra do Cipó". The study of other species will not only increase our knowledge regarding the evolution of these strategies, as it will also allow us to test hypotheses about possible trade-offs concerning the evolution of this group in the rupestrian grasslands.

Acknowledgements - The authors are grateful to Geraldo Wilson Fernandes for his valuable comments on an earlier version of the manuscript and gratefully acknowledge criticisms and suggestions made by Rogério Parentoni Martins, Kátia Torres Ribeiro and Fábio Rubio Scarano which greatly improved the paper; to Ana Maria Giulietti for all the plant identifications and a large amount of important information on the taxonomy and biology of Leiothrix; to Leonardo Viana for his help in the English translation. Also, Fernanda Rolim for drawing the schematic illustration. We also thank Ibama for permission to work and collect at the "Parque Nacional da Serra do Cipó", and for providing us with accommodations. This investigation was supported by Capes and a grant from CNPq (479929/2001-7), whose assistance we gratefully acknowledge.

\section{References}

CALDWELL, M.M. \& PEARCY, R.W. 1994. Exploitation of environmental heterogeneity by plants. Academic Press, San Diego. 
COELHO, F.F. 2005. Variação nas histórias de vida de Leiothrix (Eriocaulaceae) na Serra do Cipó, MG. Tese de doutorado, Universidade Federal de Minas Gerais, Belo Horizonte.

COELHO, F.F., NEVES, A.C.O., CAPELO, C. \& FIGUEIRA, J.E.C. 2005. Pseudovivipary in two rupestrian endemic species (Leiothrix spiralis and Leiothrix vivipara). Current Science 88:1225-1226.

COELHO, F.F., CAPELO, C., NEVES, A.C.O, MARTINS, R.P. \& FIGUEIRA, J.E.C. 2006. Seasonal timing of pseudoviviparous reproduction of Leiothrix (Eriocaulaceae) rupestrian species in Southeastern Brazil. Annals of Botany 98:1189-1195.

ELMQVIST, T. \& COX, P.A. 1996. The evolution of vivipary in flowering plants. Oikos 77:3-9.

GRACE, J.B. 1993. The adaptive significance of clonal reproduction in angiosperms: an aquatic perspective. Aquatic Botany 44:159-180.

FIGUEIRA, J.E.C. \& DEL SARTO, M.L. 2007. Clonal growth and dispersal potential of Leiothrix flagellaris (Eriocaulaceae) in the rocky grasslands of Southeastern Brazil. Revista Brasileira de Botânica 30:679-686.

GIULIETTI, A.M.1978. Os gêneros Eriocaulon L. e Leiothrix Ruhl. (Eriocaulaceae) na Serra do Cipó Minas Gerais, Brasil. Tese de doutorado, Universidade de São Paulo, São Paulo.

GIULIETTI, A.M. \& HENSOLD, N. 1990. Padrões de distribuição geográfica dos gêneros de Eriocaulaceae. Acta Botanica Brasilica 4:133-158.

GIULIETTI, A.M., AMARAL, M.C.E. \& BITTRICH, V. 1994. Phylogenetic analyses of inter- and infrageneric relationships of Leiotrhix Ruhland (Eriocaulaceae). Kew Bulletin 50:55-71.

GIULIETTI, A.M., MENEZES, N.L., PIRANI, J.R., MEGURO, M. \& WANDERLEY, M.G.L.1987. Flora de Serra do Cipó, Minas Gerais: caracterização geral e lista de espécies. Boletim de Botânica da Universidade de São Paulo 9:1-151.
HARPER, J.L. 1977. Population Biology of Plants. Academic Press, New York.

HUMPHREY, L.D. \& PYKE, D.A. 1998. Demographic and growth responses of a guerrilla and a phalanx perennial grass in competitive mixtures. Journal of Ecology 86: 854-865.

LEE, J.A. \& HARMER, R. 1980. Vivipary, a reproductive strategy in response to environmental strees? Oikos 35: 254-265.

LOVETT-DOUST, J. 1981. Population dynamics and local specialization in a clonal perennial (Ranunculus repens). I. The dynamics of ramet in cobntrasting habitats. Journal of Ecology 69:743-755.

MENEZES, N.L. \& GIULIETTI, A.M. 1986. Campos rupestres. Paraíso botânico na Serra do Cipó. Ciência Hoje 5:83-44.

PIERCE, S., STIRLING, C.M. \& BAXTER, R. 2003. Pseudoviviparous reproduction of Poa alpina var. vivipara L. (Poaceae) during long-term exposure to elevated atmospheric $\mathrm{CO}_{2}$. Annals of Botany 91:613-622.

SALISBURY, E.J. 1942. Reproductive capacity of plants. Bell, London.

SOKAL, R.R. \& ROHLF, F.J. 1981. Biometry. Freeman, San Francisco.

VAN GROENENDAEL, J.M., KLIMES, L., KLIMESOVA, J. \& HENDRIKS, R.J.J. 1996. Comparative ecology of clonal plants. Philosophical Transactions of the Royal Society B 351:1331-1339.

WINKLER, E. \& FISCHER, M. 2002. The role of vegetative spread and seed dispersal for optimal life histories of clonal plants: a simulation study. Evolutionary Ecology 15:281-301.

WIKBERG, S. \& SVENSSON, B.M. 2003. Ramet demography in ring-forming clonal sedge. Journal of Ecology 91: 847-854.

WORLEY, A.C. \& HARDER, L.D. 1996. Size-dependent resource allocation and costs of reproduction in Pinguicula vulgaris (Lentibulariaceae). Journal of Ecology 84:195-206. 